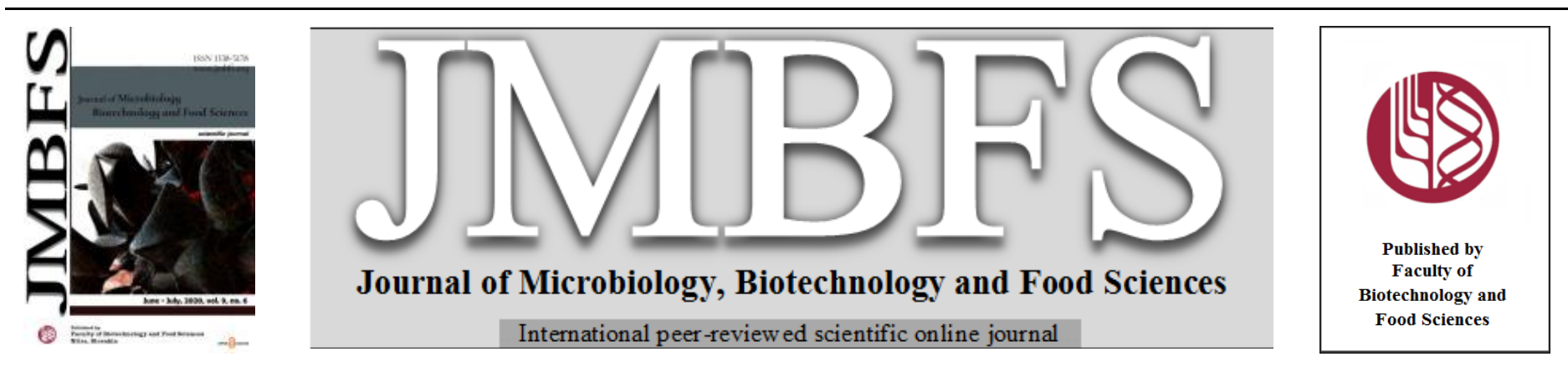

\title{
LEPTOSPIROSIS: A SYSTEMATIC REVIEW
}

\section{Rupak Nagraik ${ }^{1}$, Ankur Kaushal ${ }^{2}$, Shagun Gupta ${ }^{l}$, Avinash Sharma ${ }^{l}$ and Dinesh Kumar ${ }^{*^{*}}$}

Address(es): Dr. Dinesh Kumar,

${ }^{1}$ Faculty of Applied Sciences and Biotechnology, Shoolini University, Solan- 173229 (H.P), India.

${ }^{2}$ Amity University, Haryana- 122413, India.

*Corresponding author: chatantadk@yahoo.com

doi: 10.15414/jmbfs.2020.9.6.1099-1109

ARTICLE INFO

Received 27. 10. 2018

Revised 11. 1. 2020

Accepted 20. 1.2020

Published 1. 6. 2020

\section{Review}

open $\partial_{\text {ACCESS }}$

\begin{abstract}
Leptospirosis caused by Leptospira interrogans is considered as one of the most important zoonotic infections globally. It affects humans and wide range of animals. It damages various vital organs of the body and can often lead to fatal complications. The various symptoms of leptospirosis are fever, headache, nausea, vomiting and abdominal pain. It may lead to complications like jaundice, hemorrhage, myocarditis, meningitis and in some cases renal failure. Leptospirosis is mainly caused by rodents which are considered as reservoir hosts for leptospires. The other animals such as mammals, birds, amphibians, reptiles and fish are carriers of leptospirosis. Humans acquire leptospirosis accidently by contact with carrier animals or environment contaminated by leptospires. Leptospirosis has a wide geographical distribution including tropical, subtropical and temperate climatic regions. But it is more prevalent in the tropical areas where warm humid conditions and alkaline or neutral soil helps leptospires survive better. This review is an attempt to cover every aspect of leptospirosis in detail. The biology and culture characteristics of leptospires, classification, epidemiology, pathogenesis, host immune response, transmission cycle and different diagnostic methods have been explained in detail.
\end{abstract}

Keywords: Leptospirosis, Leptospira interrogans, Epidemiology, Transmission, Diagnosis

\section{INTRODUCTION}

Leptospirosis is the most important zoonosis worldwide (Sehgal, 2000). Due to its infectious nature it has emerged as a matter of major concern in India and many other countries. It has become endemic in some of the South East Asian countries. It is caused by the bacteria (spirochetes) belonging to the genus Leptospira (Waitkins, 1987). It occurs in varying environmental regions but is more prevalent in tropics where wet and humid conditions are highly favorable for its transmission. Leptospirosis affects humans and many other species of vertebrates. Human infection is caused by recreational exposure to water contaminated with Leptospira and therefore humans are considered to be accidental hosts whereas animals are considered reservoir hosts of Leptospira. A large number of clinical manifestations are associated with leptospirosis. It includes respiratory distress, pulmonary hemorrhage, meningitis and renal failure (Bharti et al., 2003).

\section{MORPHOLOGY AND CHARACTERISTIC FEATURES}

Leptospires are spirochetes which are highly motile and aerobic (obligate) in nature. They exhibit features common to both Gram-positive and Gram-negative bacteria (Haake, 2000). The size of the cell ranges from 6-20 $\mu \mathrm{m}$ in length and about $0.1 \mu \mathrm{m}$ in thickness. Leptospires are grown at $28^{\circ} \mathrm{C}$ to $30^{\circ} \mathrm{C}$ with $\mathrm{pH}$ in the range of 7-8 (Bharti et al., 2003). They can survive for many days in wet neutral or slightly alkaline soil and fresh water. Leptospires are poorly stained and therefore cannot be visualized by light microscopy. They can be visualized by dark field or phase-contrast microscopy. They can be stained best by silver impregnation techniques. Under the electron microscope leptospires appear cylindrical, wound helically around an axistyle $(0.01-0.02 \mu \mathrm{m}$ in diameter), which is comprised of two axial filaments (a spirochetal form of a modified flagellum) inserted sub-terminally at the extremities of the cell body, with their free ends directed towards the middle of the cell (Hovind-Hougen, 1976). A scanning electron microscopic (SEM) image of Leptospira is shown in Figure 1.

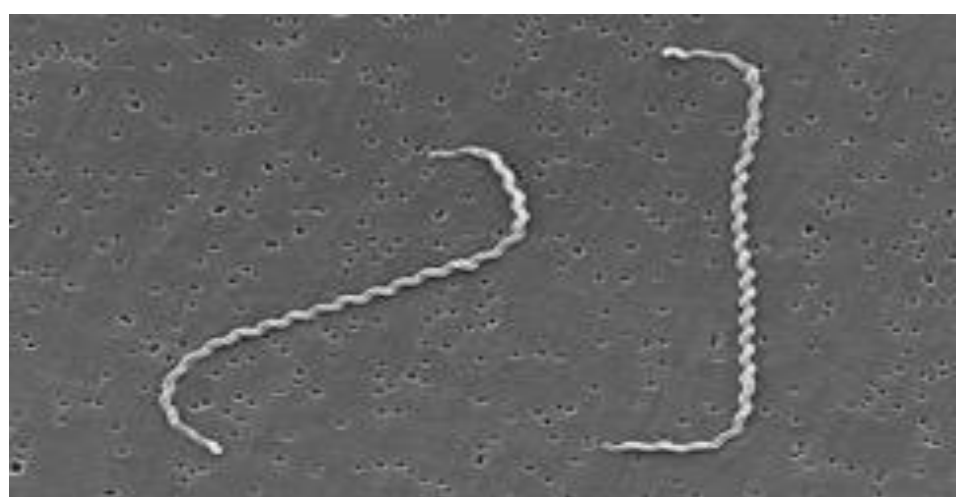

Figure 1 Scanning Electron Microscopy (SEM) images of L. interrogans serovar Icterohaemorrhagiae strain RGA (Weyant et al., 1999)

\section{CLASSIFICATION}

The taxonomical classification of leptospires is given here under:

Domain Bacteria

Kingdom Eubacteria

Phylum Spirochaetes

Division Gracillicutes

Class Scotobacteria

Order Spirochaetales

Family Leptospiraceae

Genus Leptospira

The family Leptospiraceae consists of thee genera viz., Leptospira, Leptonema and Turneria. Leptospira consists of many pathogenic and non-pathogenic serovars characterized under it. Inada and Ido in 1915 isolated the first strain of Leptospira serovar Icterohaemorrhagiae from the patient suffering from Weil's syndrome. Initially Leptospira were classified into two main types namely, namely, the L. interrogans (pathogenic) and the L. biflexa (non-pathogenic) 
(Faine and Stallman 1982). The pathogenic leptospires fail to grow at $13^{\circ} \mathrm{C}$ and in the presence of 8 -azaguanine whereas non-pathogenic ones grow at $13^{\circ} \mathrm{C}$ and are resistant to 8-azaguanine. The species $L$. biflexa fail to exhibit spherical cellular nature in $1 \mathrm{M} \mathrm{NaCl}$. There are more than 250 serovars of $L$. interrogans arranged into 25 different serogroups. L. biflexa has 65 serovars arranged into 38 serogroups. There are 20 Leptospira spp. based on DNA relatedness. This classification system does not correspond with the initial classification of leptospires based on serology because it was observed that both pathogenic and non-pathogenic serovars existed within the same species.
Current phylogenetic classification system of leptospires is based on DNA-DNA hybridization and 16S rRNA sequence analysis (Picardeau, 2017). This system divides the genus Leptospira into twenty-two species comprising three different groups. The first group consists of ten pathogenic types that cause disease in humans and animals. The second group is composed of five intermediate types which can cause mild clinical manifestations and the third group which is composed of seven types is saprophytic in nature. A classification of Leptospira based on serology, DNA-DNA hybridization and 16SRNA is shown in Figure 2.

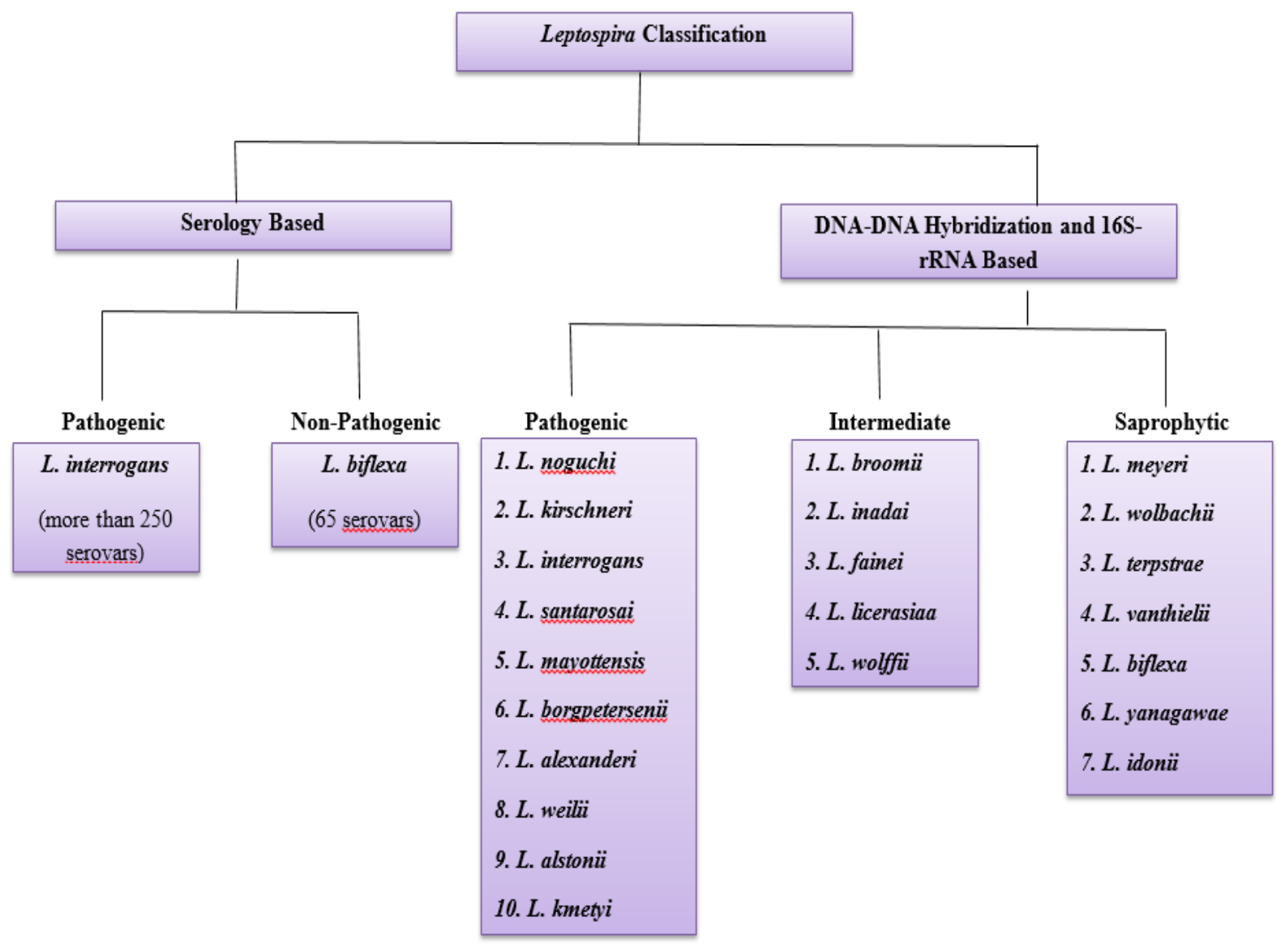

Figure 2 Classification of Leptospira

\section{CULTURAL CHARACTERISTICS}

Leptospires are aerobic bacteria that require specific and selective media for their culturing. They do not utilize carbohydrates as energy and carbon source. Instead, they depend on long chain fatty acids for their energy and carbon requirements. As free fatty acids have the inherent property of being toxic, they are supplied in esterified form or bound to albumin. Additionally, leptospires require Vitamins B1, B12, ammonium salts and iron for their optimal growth. Pyrimidine analogue 5- flurouracil and neomycin sulphate are used for selective isolation of Leptospires. The other antibiotics that have been used are polymyxin B, vancomycin and rifampicin (Ellis and Michno, 1976). Leptospires are cultured in a wide variety of culture media including liquid, solid and semi-solid media. Liquid media is used for the cultivation of leptospires for various tests. It can be converted into semi-solid media by addition of agar (0.1-0.2\%). Semi-solid media is used for isolation of leptospires and their maintenance. Solid media (Roth et al., 1961) (0.8-1\% agar) is used for research and cloning purposes. The most commonly used commercially available media is EllinghausenMcCullough-Johnson-Harris (EMJH) medium (Ellinghausen and McCullough, 1965; Johnson and Harris, 1967). In this medium long chain fatty acid is used as a nutritional source and serum albumin as de-toxicant. The other media are liquid or semi-solid in nature and contain rabbit serum. These include Korthoff's (peptone, $\mathrm{NaCl}, \mathrm{NaHCO}_{3}, \mathrm{KCl}, \mathrm{CaCl}_{2}, \mathrm{KH}_{2} \mathrm{PO}_{4}, \mathrm{Na}_{2} \mathrm{HPO}_{4}$ ), Fletcher's (peptone, beef extract, $\mathrm{NaCl}$, and agar) and Stuart's media $\left(\mathrm{CaCl}_{2}, \mathrm{C}_{3} \mathrm{H}_{7} \mathrm{Na}_{2} \mathrm{O}_{6} \mathrm{P} . \mathrm{H}_{2} \mathrm{O}\right.$ $\mathrm{C}_{2} \mathrm{H}_{3} \mathrm{NaO}_{2} \mathrm{~S}, \mathrm{C}_{3} \mathrm{H}_{8} \mathrm{ClNO}_{2} \mathrm{~S}$, methylene blue and agar) (Faine et al., 1999). Rabbit serum contains nutrients including high concentrations of bound vitamin B12 which helps in the growth of leptospires. Several protein free media have been developed which are used for the production of vaccines. The growth rate of leptospires is very slow but once they manage to grow they can be retained in liquid media for several months.

\section{LEPTOSPIRA GENOME}

A number of leptospiral genomes have been sequenced so far. In general, the Leptospira genome consists of two circular chromosomes which have variable length in different serovars. The variability in the genome helps leptospires to survive and adapt in different conditions (Picardeau et al., 2008). Leptospira interrogans serovars Copenhageni and Lai are approximately $4.6 \mathrm{Mb}$ in size whereas Leptosira borgpetersenii serovar Hardjo is $3.9 \mathrm{Mb}$ in size. Recently, the complete genome sequence of L. interrogans serovar Bratislava having two chromosomes, CI (4.457 Mbp) and CII (358 kbp) has been reported. Varni et al. (2016) reported that the genome size of L. interrogans serovar Pomona is approximately $3.6 \mathrm{Mb}$ with 3763 annotated genes.

\section{EPIDEMIOLOGY}

Leptospirosis is widely distributed geographically and occurs mostly in tropical subtropical and temperate zones (Ratnam, 1994). Though the incidence has decreased in developed countries but in the developing countries there has been considerable increase in leptospirosis cases. In some countries such as Thailand where leptospirosis is under surveillance the occurrence has increased overwhelmingly (Tangkanakul $\boldsymbol{e t}$ al., 1998). It is declared endemic in most of the South East Asian countries. A number of leptospirosis outbreaks have occurred in the past in various places across the globe.

\section{Leptospirosis in India}

Leptospirosis was reported first in Andaman and Nicobar Islands in the year 1929 (Kamath and Joshi, 2003) and has since spread to different parts of India. Leptospira andamans and Leptospira grippotyphosa were isolated in the Andamans (Taylor and Goyle, 1931). Several other cases of leptospirosis were reported where leptospires were isolated from humans. Leptospiral serovar 
Icterohaemorrhagiae and Canicola antigens were found in five cases of jaundice in the year 1960 (Dalal, 1960). In 1966, two serovars of leptospirosis viz. Icterohaemorrhagiae and Canicola were confirmed by agglutination lysis test in PUO (Pyrexia of Unknown Origin) cases out of 93 sera samples. Joseph and Kalra (1966) reported that out of 43 cases of jaundice in Delhi, two samples tested positive for serovar Icterohaemorrhagiae and one was found positive for both serovars Icterohaemorrhagiae and Pomona. One year later in Bombay in 1966, leptospiral infection due to Leptospira pyrogenes was evident in one sample out of 93 sera samples for infective hepatitis (Bhatnagar et al., 1967). In 1983 , there was prevalence of leptospiral serovars in $18 \%$ and $24 \%$ of jaundice and PUO cases respectively (Ratnam et al., 1983). Consequent to bovine leptospirosis outbreak in Chennai, several children in Tamil Nadu tested positive for leptospirosis giving good antibody titer. Leptospirosis was the main cause of acute renal failure in 19 human patients in Madras (Muthusethupathi and Shivakumar, 1987). Venkataraman et al. (1991) confirmed that $33(82.5 \%)$ patient samples out of 40 had specific leptospiral antibodies as confirmed by MAT. During November and December 1990 to 19991 as many as 54 patients with clinical features such as fever, jaundice, myalgia, conjunctival suffusion and acute renal failure were admitted to Government General Hospital, Madras. Leptospiral antibodies were found in two cases and one patient sample confirmed the presence of Leptospira serogroup Autumnalis (Muthusethupathi et al., 1995). Ratnam et al. (1993) reported 32.9\% prevalence rate of leptospirosis during a surosurvey conducted among conservancy workers of Madras as confirmed by MAT. Diglipur, in North Andamans witnessed an outbreak of acute febrile illness involving hemorrhagic and pulmonary associated symptoms during October to November of the year 1993. Leptospiral antibodies were recorded in $66.7 \%$ of the patient population (Sehgal et al., 1995). In the year 1994, following severe flooding of Tamil Nadu in the autumn of 1993, a sudden increase in uveitis cases due to epidemic leptospirosis was observed at Aravind Eye hospital, Madurai. Out of 46 patients, $80 \%$ of them tested positive for leptospiral DNA and 72\% tested serologically positive (Kathryn et al., 1998). In 1995, leptospirosis was reported serologically in $12 \%$ patients of jaundice and febrile illness in Pondicherry (Prabhakar et al., 1995). From the month of July to Novembe 1996, thirty-eight acute renal failure cases were tested for clinically suspected leptospirosis in Chennai. Twenty-seven patients (71\%) were reported to be seropositive as confirmed by MAT (Saravanan et al., 1998). In 1999, several people suffered from febrile illness with hemorrhagic manifestations after a cyclone hit Orissa followed by floods. Out of 142 patients tested, 28 samples confirmed the serological evidence of leptospiral infection (Sehgal et al., 2001) Krande et al. (2002) reported the occurrence of an outbreak of leptospirosis in children living in flood areas of Mumbai. The children presented symptoms viz. fever, bodyache, chills, abdominal pain, headache, vomiting, cough, hepatosplenomegaly, edema and crepitations. Out of 93 children samples tested, $30(32 \%)$ were confirmed with acute leptospiral infection, 22 with anicteric leptospirosis and 8 were confirmed with Weil's disease. In 2005, Mumba witnessed an outbreak of leptospirosis as a consequence of severe flooding. The incidence and fatality rates increased to 7.85 per 0.1 million and $8.7 \%$ respectively in contrast to 2.1 per 0.1 million and $7.3 \%$ when there were no floods (Kshirsagar et al., 2006). Sharma et al. (2006) reported the prevalence of L. interrogans serovar Hardjo in suspected dairy farm cases in Tirupati region of Andhra Pradesh. Velineni et al. (2007) reported the occurrence of leptospirosis in humans based on data collected from different hospitals of Hyderabad. $L$ interrogans serovars Icterohaemorrhagiae $68 \%$, Australis $22 \%$, Autumnalis $8 \%$ and Javanica $2 \%$ were found in 55 patient samples tested by MAT, IgM ELISA and LeptoTek Dri-dot. Masali et al. (2007) reported the prevalence of leptospirosis in six villages of Karnataka. In 2011, Karnataka and southern part of Gujarat witnessed 130 deaths due to leptospirosis. Leptospirosis struck Surat and Valsad districts of Gujarat in the year 2012. Brihanmumbai Municipal Corporation (BMC) in Mumbai reported 15 leptospirosis deaths within a short span of ten days (Chaurasia, 2016). Before the onset of monsoon in 2016, four persons died due to leptospirosis in Udipi area of Karnataka. Recently in 2018 after the Kerala floods as many as 77 cases of leptospirosis have been reported.

\section{Leptospirosis around the world}

Leptospirosis has a global impact on human health and is considered to be burdening the world economy. More than 60,000 people die due to leptospirosis annually and nearly one million are reported to be affected (Mwachui $\boldsymbol{e t}$ al., 2015). During the past several years a large number of leptospirosis outbreaks have shook many parts of the world. In addition to Indian sub-continent Oceania, Caribbean and Latin America are considered to be endemic to leptospirosis (Pappas et al., 2008). Leptospirosis has been reported to affect all five continents and many countries because of the favorable climatic conditions (Sehgal, 1998). An outbreak of leptospirosis struck US army in the year 1961 after exercising in the jungle a few days earlier (Gale et al., 1966). During 1975-1977, leptospiral seroprevalence was reported in different work groups in the Barbados. It was found highest in sanitation workers $(42.7 \%)$ followed by sugarcane workers (39.4\%). In a serosurvey conducted in northern Trinidad between mid-1977 and mid-1978, leptospirosis infection was reported widely in people with a highest prevalence rate of $45 \%$ in sugarcane workers. $9 \%$ new and 23\% re-emergent leptospiral cases were reported during 1977-1982 once again in Trinidad (Everard et al., 1987). A high seroprevelence of leptospirosis was reported in Somalia in the year 1982 (Cacciapuoti et al., 1982). In a serosurveillance study conducted in Italy in the year 1987, leptospirosis was confirmed in $11.34 \%$ rural and 3.08\% urban area cases of central Italy (Cacciapuoti et al., 1987). In 1987, leptospirosis was confirmed in 14 patients out of 56 patients being hospitalized in Karachi province of Pakistan (Ahmed, 1987). In Barbados and Trinidad region of Caribbean basin leptospirosis was confirmed in $12.5 \%$ and $9.5 \%$ schoo children (aged between 9-14 yrs) respectively in the year 1988 (Everard et al., 1989). Park et al. (1989) reported the occurrence of several outbreaks of leptospirosis in Korea due to flooding of fields before the harvesting season. Within the US the most number of leptospirosis cases have been reported in Hawaii (CDC report, 1998). In 1992 it was reported by Hawaii State Health Department that the incidence rate of leptospirosis in Hawaii was $2.97 \%$ per 10000 people as compared to nationwide rate of $0.2 \%$ per 100000 people. In Hawaii though the leptospirosis incidence associated with occupational exposure decreased from 56\% during 1971-1975 to 29\% during 1986-1990 but the incidence associated with recreational, habitational and vocational exposure increased from 43\% during 1971-1975 to 71\% during 1986-1990 (Katz et al., 1977). Many cases of Acute Renal Failure (ARF) due to leptospirosis have been reported in 1977 and 1993 in Uruguay (Raul, 1977). Faine (1994) reported that the incidence of leptospirosis increased from 0.3/100,000 (between1982-1987) individuals to 3/100,000 individuals (between1997-1998) in Thailand. A large number of symptomatic leptospirosis cases viz. 80 cases during 1989 to 1990,65 cases during 1993 to 1994 , and 75 cases during 1995 to 1996 were observed in Seychelles (Yersin et al., 1998). Nicaragua witnessed an outbreak of leptospirosis in October, 1995 following heavy water flooding. As many as 2259 patient samples were analyzed for non-malarial febrile illness with cumulative incidence of $6.1 \%$ and $0.7 \%$ pulmonary hemorrhagic fatality rate (Zaki and Sheih, 1996)

Ceceroni et al. (1995) reported the prevalence of leptospirosis in the Cordillera province of Bolivia. 90 out of 295 samples tested, showed the presence of Leptospira antibodies as confirmed by MAT. An outbreak of leptospirosis was reported in the urban areas of El Salvador, Brazil (Koi et al., 1999). An active surveillance system was set up in a hospital in Brazil between March 10 and November 2, 1996. Surveillance identified 326 suspected cases and Leptospira interrogans serovar copenhageni was isolated from $87 \%$ of the cases with positive blood cultures. The case fatality rate was $15 \%$ despite aggressive supportive care. The diagnosis was confirmed using MAT and identification of leptospires in blood or urine samples. Initially $42 \%$ of the cases were misdiagnosed as having dengue in the outpatient clinic due to simultaneous dengue outbreak in the region. Leptospirosis was also reported in Turkey where leptospiral antibodies were detected by MAT in 5.48\% of patient samples out of 1440 total samples tested (Leblebicioglu et al., 1996). In 1996, leptospirosis outbreak was reported in Rio de Janeiro after heavy rainfall resulting in persistent flooding of the western region (Barcellos and Sabroza, 2001). In the same year an outbreak of leptospirosis was reported in Costa Rica among white water rafters who exhibited unknown febrile illness as reported by a physician to Illinois Department of Public Health (MMWR June 1997, CDC). A random survey was conducted in Seychelles in which 1067 patient samples were analyzed out of which 37\% showed prevalence of leptospiral antibodies (Bovet $\boldsymbol{e t}$ al., 1999). A survey was conducted in North-eastern Alpine regions of Italy to study the epidemiology of leptospirosis. A seroprevelence rate of 10\%-12\% was detected in farmers and forestry workers of the region (Nuti et al., 1993). In July, 1998 leptospirosis was reported to cause acute febrile illness in athletes in Wisconsin and Illinois (MMWR July 1998, CDC). During a sporting event (Sabah) in Malaysia in 2000, 80 cases of leptospirosis were confirmed in athletes participating in different water related activities (Anderson et al., 1978). In Dhaka, Bangladesh leptospirosis was confirmed by PCR in 63 patients out of 359 dengue negative patient samples (LaRocque et al., 2005). In Indonesia Leptospira serovars Bataviae and Hardjo were reported as a causative agent of leptospirosis infection between 2001 and 2002. A total of 557 (139 in 2001 and 418 in 2002) serum samples were tested during this period and Leptospira serovar Bataviae and Hardjo was reported in $18.7 \%$ and $12 \%$ cases respectively (Hartskeel, 2002).

In China, 1500 confirmed cases of leptospirosis were reported by health department between January 2002 and October 2007 (A report by Medical News Today 2007). In 2007, a total number of 208 cases of leptospirosis were reported in rural areas of Korea in which mostly rice field farmers were affected. According to National Leptospirosis Surveillance report 2008, 112 cases of leptospirosis were reported in Australia. In 2009, leptospirosis was reported in 471 patients in the Philippines following heavy flooding caused by a typhoon (Shere et al., 2009). In 2014, 90 cases of leptospirosis in United States were reported in soldiers when they were attending jungle warfare exercises (Burns $\boldsymbol{e t}$ al., 2015). In 2016 in the Dominican Republic, 74 death cases of leptospirosis were reported by Outbreak News today. The same agency recently reported $68 \%$ cases of leptospirosis in the Philippines in the year 2017. In the year 2018, a total of 368 leptospirosis cases were reported by The Philippines Department of Health between January 1 and July 3 in Manila Metro. 


\section{TRANSMISSION CYCLE AND MODES OF TRANSMISSION}

Humans are considered to be the accidental hosts as a result of direct or indirect contact with leptospirosis infected animals. Animal hosts of leptospirosis may be either carrier or reservoir hosts, the latter being the primary source of infection. Though the presence of animal carrier is considered important in leptospirosis transmission but it can occur through various environmental sources. Leptospires being ubiquitous in nature are found everywhere but their primary habitat is renal tubules of carrier animals. Large species of rodent, mammal and marsupial can be carrier or reservoir of leptospirosis. Leptospira serovar Icterohaemorrhagiae has been associated with rodents (Matthias and Levett, 2002). Other serovars have been associated with different mammalian hosts (Farr, 1995). Cattle for example, can be infected with Leptospira serovars Hardjobovis, Pomona, Bratislava and Grippotyphosa though other serovars have also been reported (Vijayachari et al., 2008). Pigs are commonly infected with serovars Pomona,
Tarassovi, Grippotyphosa, Bratislava, Sejroe and Icterohaemorrhagiae whereas serovars Canicola and Icterohaemorrhagiae have been associated with infection in dogs (Vijayachari et al., 2008). Leptospirosis has also been reported in various wild animals such as bats, possums, deer, mongoose and small insectivores (Ellis, 2015).

Leptospirosis has direct and indirect mode of transmission. Direct transmission occurs through leptospires from tissues, body fluids or urine of acutely infected or asymptomatic carrier animals. The most common method of entry is through the skin. They can directly travel in to the blood or lymphatic system through conjunctiva or into the lungs through inhalation as aerosols (Faine, 1994). In animals it can be transplacental, haematogenous, by sexual contact or by suckling milk from infected mother. The direct infection from mother to child via placenta and the occurrence of leptospires in genital tracts have been reported in animals (Ellis et al., 1986). Transmission cycle of Leptospira is shown in Figure 3. On the other hand, indirect transmission occurs from the environmental leptospires.

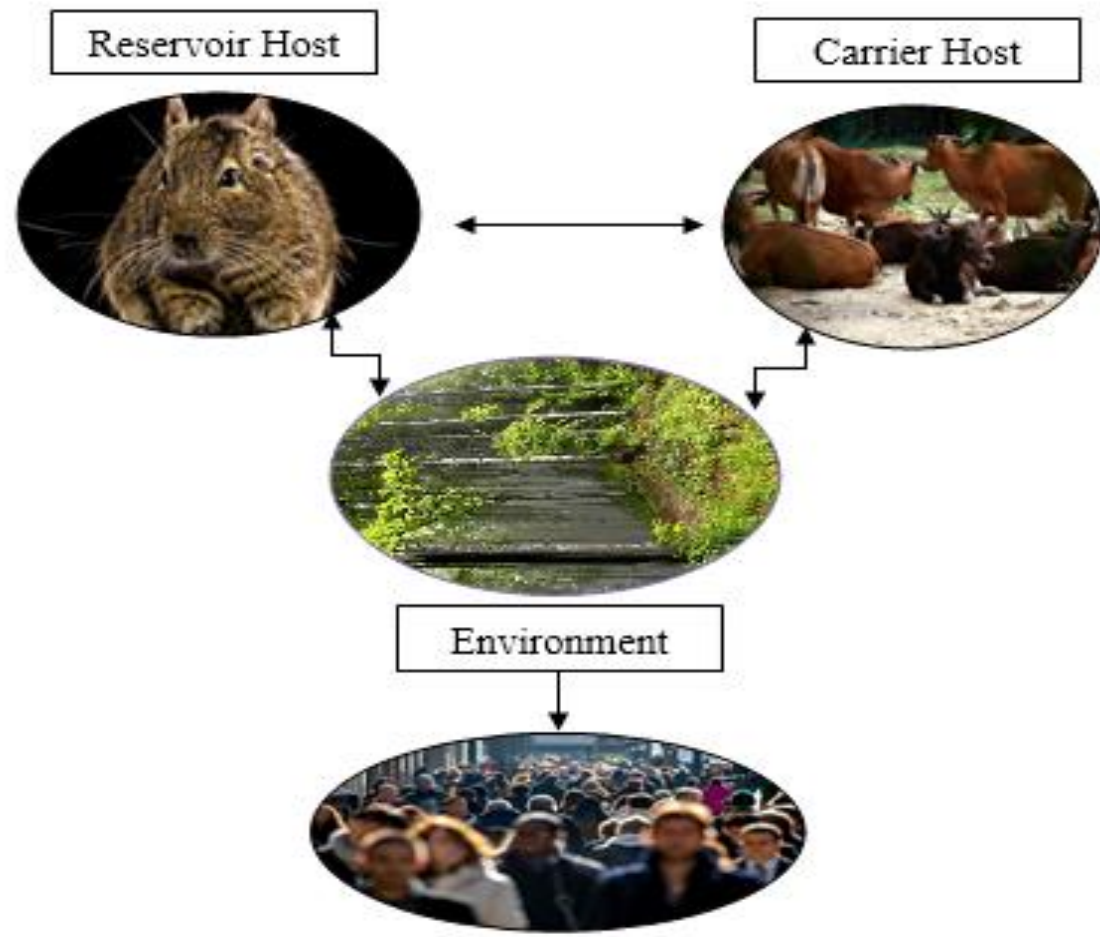

Human Population

Figure 3 Transmission cycle of Leptospira

\section{POPULATION AT RISK AND RISK FACTORS}

Leptospirosis in humans is mainly caused due to various occupational and recreational activities. People belonging to different workgroups such as butchers, farmers, veterinarians, rodent control workers and others who are directly involved in any work associated with animals are at higher risk (Demers et al., 1985; Terry et al., 2000; Thornley et al., 2002). Leptospirosis has been considered as an important health hazard of rice farmers in Indonesia and Thailand (Tangkanakul, 1998). Leptospirosis outbreak has occurred in Chonbuk province of Korea due to heavy flooding before harvest (Park $\boldsymbol{e t}$ al., 1989). An outbreak of leptospirosis occurred in a dairy farm in east Otago in New Zealand (Thomas et al., 1994). Leptospirosis has also been associated with various water related recreational activities and water sports (Levett, 2001) Leptospirosis infection was reported in participants of Eco-Challenge multi-sport endurance event organized in Borneo, Malaysia in September 2000. Recently in July 2011, leptospirosis has been reported in France. Various other serogroups have been reported to cause infection in humans engaged in different water related recreational activities (Sejvar et al., 2003). A number of cases of leptospirosis have been reported associated with swimming in contaminated water and human to human infection through breast feeding (Corwin et al., 1990). During a scout camp in Belgium in 2012, leptospirosis was reported in boys attending the camp and the source of infection was attributed to be forest rats. Depending on the social behavior, occupation and environmental factors there is a modulated epidemiological risk associated with leptospiral infection.

\section{PATHOGENESIS AND VIRULENCE FACTORS}

The mechanisms by which leptospires causes pathogenesis are not clearly understood. Attachment to the host cell surface and production of toxins are the two important characteristics of leptospires. leptospires enter the host by small cuts or openings in the skin, eye conjunctiva, mucous membrane, genital tract and spread quickly through blood and lymphatic system to different parts of the body. They can circulate in the blood stream lasting up to seven days (Adler et al., 2010). Chemotaxis and motility of leptospires play an important role in invasion and spreading of infection (Charan and Goldstein, 2002). The ability to penetrate and move rapidly has been demonstrated on various cell lines (Liu $\boldsymbol{e}$ al., 2007). Outer membrane of leptospires possesses antiphagocytic activity (Levett, 2001). A large number of virulence factors have been associated with the occurrence of leptospirosis. Particularly, outer membrane proteins (OMPs) play a key role in pathogenesis of leptospirosis. OMP LipL32 is a highly conserved virulence factor present in pathogenic leptospires (Haake $\boldsymbol{e t}$ al., 2000) Other proteins such as integrin alpha like protein, cell surface polysaccharides and exopolysaccharides are also considered potential virulence factors for leptospirosis (Isogai et al., 1997). Leptospires are believed to interact with extracellular matrix (ECM) proteins of the host organism. The proteins such as LigA LigB, Lsa21, Lsa24 and Loa22 are the potential virulence factors that interact with ECM of the host (Choi et al., 2007; Atzingen et al., 2008; Barosa et al., 2006; Ristow et al., 2007).

\section{PRODUCTION OF TOXINS}

One characteristic that determines the pathogenicity of leptospires is the production of endotoxins. Several serovars of Leptospira are being reported to exhibit endotoxin production. It has been reported that leptospiral lipopolysaccharides (LPS) are believed to show evidence of endotoxin production like other Gram negative bacteria. Shimiju et al. (1987) reported that biological activity of LPS from $L$. interrogans serovar canicola was lesser as compared to the other Gram negative bacteria. This may be due to differential 
immunity activation mechanism in leptospires and other Gram negative bacteria Glycolipoprotein (GLP) fractions in leptospires are also believed to exhibit cytotoxic effects (Vinh et al., 1986). Such type of activity was first observed in Leptospira serovars Copenhaegi and Pomona (Cinco et al., 1980). In serovar Canicola GLP fractions of similar kind were reported to inhibit the activity of enzyme $\mathrm{Na}^{+} / \mathrm{K}^{+}$ATPase due to the adsorption of unsaturated fatty acids to GLP fraction (Burth et al., 1997). Leptospires also produce haemolysins that act on red blood cells and other cells having phospholipids in their membranes (Lee $\boldsymbol{e}$ al., 2002). These are believed to be phospholipases that act on substrates having phosphplipids. Some serovars of leptospirosis viz. Pomona and Hardjo also exhibited sphingomyleinase C activity (Bernheimer and Bey, 1986; del Real et al., 1989). Based on the ability of hemolysins to hydrolyze sphingomylein they are categorized as sphingomyelinase and non-sphingomyelinase hemolysins (Zhang et al., 2005).

\section{HOST IMMUNE RESPONSE}

The first line of host defense that helps in the recognition and elimination of leptospires is the innate immune system. The activation of complement system kills the non-pathogenic Leptospira biflexa within a few minutes in vitro but pathogenic virulent Leptospira species are more resistant to the compliment system (Barbosa et al., 2009). The innate response in case of leptospirosis is dependent on the recognition of certain patterns known as pathogen associated molecular patterns (PAMPs) (Beutler, 2004). These PAMPs are recognized by proteins called pathogen recognition particles (PRRs) present on the host immune cells. These PRRs helps the cells to recognize conserved motifs in microbial cells such as lipopolysaccharides and peptidoglycans (Kawai and Akira, 2007). These signaling PRRs can be either Toll-like receptors (TLRs) or Nod-like receptors (NLRs) (Mogensen, 2009). So far in leptospirosis, the role of TLR2 and TLR4 is being studied extensively. LPS in leptospires is reported to activate TLR2 dependent signaling cascade whereas all other Gram negative bacteria activate TLR4 dependent signaling cascade (Wert $\boldsymbol{e t}$ al., 2001). This difference in mode of activation is due to the unusual composition of Lipid A in leptospires (Que et al., 2004)

The acquired immune response which is based on the production of antibodies requires the activation of classical compliment system. The main mechanism of immunity in leptospires is considered to be humoral which is believed to be serovar specific (Alder and Faine, 1999). The immunization mostly with antiLPS antibodies confers immunity against leptospirosis (Jost et al., 1986). The outer membrane proteins of leptospires play an important role in determining the host immune response. LipL32 happens to be the most dominant outer membrane protein that triggers immune response against leptospirosis in humans (Hauk $\boldsymbol{e}$ al., 2008). Another outer membrane protein LipL21 which belongs to serovar Lai of Leptospira interrogans is also reported to be having immunogenic potentia (He et al., 2008). Immunoglobulin M (IgM) antibodies are the first to occu followed by immunoglobulin $\mathrm{G}$ (IgG). Humoral immunity studies involving LPS and seven other proteins were carried out which showed the IgM antibodies specific to LPS and IgG antibodies to all seven proteins selected as targets (Guerreiro et al., 2001).

Cell mediated immunity (CMI) is also exhibited by the leptospiral host in addition to humoral immunity. It has been reported that cattle immunized with killed Leptospira borgpetersenii vaccine developed increased interferon- $\gamma$ (IF- $\gamma$ ) associated with CD4+ T cells and $\gamma \delta \mathrm{T}$ cells (Brown et al., 2003). Leptospira interrogans glycolipoprotein (GLP) activated peripheral blood mononuclear cells (PBMCs) that resulted in high amount of TNF- $\alpha$ and IL-6 (Dorigatti et al. 2005). In another study, GLP extracted from Leptospira interrogans serovar Copenhageni activated PMBCs by secreting TNF- $\alpha$ and IL-10 but nonpathogenic Leptospira biflexa serovar Patoc failed to activate PMBCs (Diment et al., 2002). Though humoral immunity remains to be the choice of immune response in Leptospira host but other mechanisms cannot be ruled out. The efficient vaccination can only be developed after understanding the varied host immune response mechanisms of leptospirosis.

\section{CLINICAL MANIFESTATIONS}

The clinical presentation of leptospirosis is highly variable. The incubation period is generally 7-14 days but it may vary ranging from 2 days to one month Leptospirosis signs and symptoms mimic several other diseases and therefore the diagnosis becomes difficult. The most cases of leptospirosis recover without any complications. But some are misdiagnosed and this makes leptospirosis an underreported disease (Heuer et al., 2008). Leptospirosis course in humans is considered to be having two phases- septicemic and immune. The acute or septicemic phase lasts up to a week and is characterized by the presence of leptospires in blood, cerebrospinal fluid etc. Various signs such as fever, myalgia, chills, headache etc. occur during this phase. The septicemic phase is followed by the immune or delayed phase characterized by the production of antibodies and occurrence of leptospires in the urine (Levett, 2001). The disease at this stage is transferred from the blood vessels to various vital organs of the body. At this point the disease can be characterized as either anicteric or icteric. The anicteric leptospirosis is the milder form and occurs in $90 \%$ of the cases. Icteric form of leptospirosis is known as Weil's disease and is the severe form of disease which occurs in $5-10 \%$ patients with $5-40 \%$ mortality (Izureita et al., 2008). It is characterized by the involvement of many vital organs of the body (Vinetz, 2001).

The disease onset in leptospirosis is very quick and is characterized by fever ranging from $100-105^{\circ} \mathrm{F}$ along with consistent headache. The pain is also witnessed in the lower part of the body such as thighs, calves etc. but the involvement of other parts of the body is also prominent (Kelley, 1998) Prostrations, anorexia, nausea, vomiting along with constipation or diarrhea are other markers of anicteric leptospirosis. A person may experience hallucinations and stays in confusing state of mind. The signs of aseptic meningitis are also observed in younger patients). Some patients may suffer from gastroenteritis discomfort and pain in the abdominal region. Encephalitis and uveitis has also been reported in some cases (Guerra 2009). Conjunctival suffusion is also observed during initial phase in some cases with no inflammatory discharge ruling out the chances of true conjunctivitis. Hemorrhagic pneumonia with acute respiratory syndrome has also been reported recently in anicteric form of leptospirosis (Grzeszczuk, 2007). Fatality rate in anicteric leptospirosis is almost zero (Edwards and Domm, 1960) but deaths in some patients were observed in China (Wang et al., 1965).

Icteric form of leptospirosis (Weil's disease) occurs in very small proportion of people. Leptospira serovar Icterohaemorrhagiae happens to be associated with most cases of icteric leptospirosis (Katz et al., 2001). The most common symptom of this form is jaundice which may occur in the initial days or later during the progressive phase of the disease. Hepato-cellular necrosis occurs and increased amount of bilirubin in the serum is also observed. Mild increase in transaminases and alkaline phosphatases may be observed. Death may also occur but at the latest stage of icteric leptospirosis due to renal failure. Most patients of kidney failure also have hepatic involvement. Cardiac involvement has also been observed in the form of myocarditis and pericarditis (Chukurkar et al., 2008) Pulmonary hemorrhage associated with leptospirosis has also been reported (Vijayachari et al., 2003). In the pregnant women leptospirosis infection can cause miscarriage in most of the cases (Carles et al., 1995).

\section{LEPTOSPIROSIS DIAGNOSIS}

Efficient laboratory diagnosis of leptospirosis becomes very essential because its clinical signs and symptoms mimic those characterized in various other diseases and disorders. There are several conditions that present febrile illness as in leptospirosis viz. influenza, meningitis, liver infections, virus invasion etc (Levett, 2001). Leptospirosis cannot be diagnosed alone on the basis of clinical manifestations it exhibits but an array of laboratory diagnostic methods is required for correct diagnosis. Understanding the course of the disease, right specimen selection and the choice of diagnostic test are the essential factors that help in precise leptospirosis diagnosis. Some of the common diagnostic procedures used during different stages for leptospirosis are given in Table 1 .

Table 1 Various diagnostic methods of leptospirosis

A. Leptospiraemic Phase <7days

\begin{tabular}{l|l|l|l}
\hline $\begin{array}{l}\text { Sr. } \\
\text { No. }\end{array}$ & Test & Sample Required & Reference \\
\hline $\mathbf{1}$ & Isolation (Bacterial Culture) & Blood, Urine, CSF & O'Keefe, 2002 \\
\hline $\mathbf{2}$ & $\begin{array}{l}\text { Direct Antigen Detection } \\
\text { 1. Dark Field Microscopy }\end{array}$ & Urine & $\begin{array}{l}\text { Levett } \text { et al., 2006, Turner, 1970 } \\
\text { Yener and Keles, 2001 } \\
\end{array}$ \\
& $\begin{array}{l}\text { 2. Histological Staining } \\
\text { 3. Immunological Staining }\end{array}$ & $\begin{array}{l}\text { Kidney lysate } \\
\text { Kidney lysate }\end{array}$ \\
& 4. Monoclonal Antibody & Urine & \\
& & & \\
\hline
\end{tabular}




\begin{tabular}{|c|c|c|c|}
\hline 3 & $\begin{array}{l}\text { PCR Based Methods } \\
\text { 1. PCR } \\
\text { 2. Real Time PCR } \\
\text { 3. REA } \\
\text { 4. RFLP } \\
\text { 5. PFGE } \\
\text { 6. PCR-RFLP } \\
\text { 7. RAPD } \\
\text { 8. FAFLP } \\
\text { 9. MLVA } \\
\text { 10. MLST } \\
\text { 11. LAMP } \\
\text { 12. LSSP-PCR } \\
\text { 13. Nucleic Acids probes } \\
\text { 14. AP-PCR } \\
\text { 15. Ribotyping }\end{array}$ & $\begin{array}{l}\text { DNA from Isolates } \\
\text { or Clinical Samples }\end{array}$ & $\begin{array}{l}\text { Terpstra et al., } 1986 \\
\text { Ahmed } \text { et al., } 2009 \\
\text { Marshall } \text { et al., } 1981 \\
\text { Li } \text { et al., } 2009 \\
\text { Galloway and Levett, } 2008 \\
\text { Li } \text { et al., } 2009 \\
\text { Ramadass } \text { et al.,1997 } \\
\text { Vijyachari } \text { et al., } 2004 \\
\text { Pavan } \text { et al., } 2011 \\
\text { Wiess } \text { et al., } 2016 \\
\text { Notomi } \text { et al., } 2000 \\
\text { Bomfim and Koury, } 1991 \\
\text { Terpstra } \text { et al., } 1986 \\
\text { Perolate } \text { et al., } 1994 \\
\text { Perolate } \text { et al., } 1994\end{array}$ \\
\hline \multicolumn{4}{|c|}{ B. Immune Phase $>7$ days } \\
\hline Sr. No. & Test & Sample Required & Reference \\
\hline 1. & $\begin{array}{l}\text { Serological Based Method } \\
\text { 1. CAAT }\end{array}$ & $\begin{array}{l}\text { Viable isolates of } \\
\text { Leptospira }\end{array}$ & Dikken and Kmety, 1991 \\
\hline 2. & $\begin{array}{l}\text { Antibody Based Methods } \\
\text { 1. MAT } \\
\text { 2. MSAT } \\
\text { 3.MCAT } \\
\text { 4. CF } \\
\text { 5. HL } \\
\text { 6. IFA } \\
\text { 7. IHA } \\
\text { 8. Dipstick } \\
\text { 9. ELISA } \\
\text { 10. Lepto tri-dot } \\
\text { 11. Lepto lateral flow } \\
\text { 12. LAT } \\
\text { 13. Flow Cytometry } \\
\text { 14. Lepto dri-dot } \\
\end{array}$ & $\begin{array}{l}\text { Serum,Urine,CSF, } \\
\text { Kidney Lysate }\end{array}$ & $\begin{array}{l}\text { Dutta and Christopher, } 2005 \\
\text { Sumathi } \text { et al., } 1997 \\
\text { Arimitsu et al., } 1982 \\
\text { Terzin, } 1956 \\
\text { Cox, } 1957 \\
\text { Appassakij et al., } 1995 \\
\text { Sulzer } \text { et al., } 1975 \\
\text { Vijayachari and Sehgal, } 2006 \\
\text { Wasinki and Pajsek, } 2010 \\
\text { Smits } \text { et al., } 1999 \\
\text { Sehgal } \text { et al., } 2003 \\
\text { Senthilkumar } \text { et al, } 2008 \\
\text { Yitzhaki } \text { et al., } 2004 \\
\text { Sehgal } \text { et al., } 1999\end{array}$ \\
\hline
\end{tabular}

\section{Direct examination of body fluids for leptospires using dark field microscopy}

Various body fluids such as blood, cerebrospinal fluid (CSF), urine and dialysis solution can be examined directly under the dark field microscope for the rapic detection of leptospires (O'Keefe, 2002). They may appear coiled and thin with active motility when examined in fluids under the dark field microscope (Levet et al., 2006). Apart from body fluids they can be examined from tissue samples extracted from various sources such as necrotic tissues, abortion products, carcasses etc. (Faine $\boldsymbol{e t}$ al., 1999). The concentration of leptospires during the initial stage of infection is low for direct microscopic examination. Their concentration in blood or urine can be increased by differential centrifugation. Approximately $10^{4}$ leptospires $/ \mathrm{ml}$ are required for one cell per field to properly visualize them in urine under dark field microscope (Langston and Heuter, 2003). Leptospires are not stained or poorly stained by Gram staining. Silver impregnation methods work well for staining leptospires. Various other staining methods such as immunohistochemical staining, immunofluorescent staining, Warthin-Starry staining etc. have been used to increase the sensitivity of dark field microscopic examination of leptospires (Yener and Keles, 2001). Though dark field microscopy becomes the only choice for the examination of leptospires due to non-availability of other resources but it is not always considered the best option. Table 3 shows various diagnostics methods used for Leptospira detection. Due to its low sensitivity and specificity it cannot be used for routinely diagnosis of leptospirosis (Levett, 2001). In addition, it requires high expertise and very careful examination of the specimen along with cross confirmation with other tests (Musso and Scola, 2013).

\section{Isolation and culture-based methods}

Leptospires can be isolated from various sources such as blood, urine, CSF and lysis solution. The isolation source and culturing of leptospires mainly depend on the stage and course of the disease. The most important source for leptospires during the initial phase (leptospiraemic phase) of leptospirosis is considered to be blood but culturing should be done within ten days from the disease onset (Schreier et al., 2013). Blood may contain $10^{2}-10^{6}$ leptospires per milliliter (Agampodi et al., 2012). Ellinghausen- McCullough Johnson-Harris (EMJH) media and Fletcher's media can be used for culturing leptospires from blood but most common use is of EMJH media (Levett and Haake, 2010). Fastidious growth can be achieved by adding $0.1 \%-0.15 \%$ agarose and $0.4-1 \%$ of fetal calf or rabbit serum. Regular examination using dark field microscopy should be done till the last week. The culture media can be made selective to avoid contamination by the use of 5-Flourouracil and a combination of antibiotics such as vancomycin, nalidixic acid, polymyxin $\mathrm{B}$, rifampicin and bacitracin but use of selective media can reduce the chances of isolation of pathogen of interest. The use of blood culture for regular determination of leptospires cannot be done because of disadvantages such as long incubation period required, cumbersome to perform and slow sensitivity. Apart from blood, leptospires can also be isolated during the initial stage of the disease from CSF and dialysate (Ahmed $\boldsymbol{e}$ al., 2005). The cultures should be taken in initial 5-10 days of the infection and the same procedure as used for blood culture should be followed. Culturing from urine can be done during leptospiruria phase of the disease. The ideal time for urine culture is between 10-30 days from the onset of leptospirosis though the duration of excretion in urine may vary (Bal et $\mathbf{a l}$., 1994). Urine culture becomes less sensitive due to intermittent leptospire shedding in humans and animals, acidic nature of urine and high chances of contamination (Fearnley et al., 2008) Leptospires can also be cultured from fatal cases in human and animal postmortem tissues such as brain, liver, kidney and aborted animal fetuses (Faine et al., 1999). Leptospires require varied time periods for growth after culturing. Less fastidious serovars such as Grippotyphosa and Pomona may exhibit good culture growth after inoculation with but some serovars such as Hardjo may take even several months to grow. Though culture-based methods are considered to be 
the most reliable and definite methods for leptospirosis diagnosis but they cannot be used for quick routinely disease diagnosis because of several shortcomings Being time consuming, less sensitive and labor intensive makes them unsuitable for laboratory diagnosis of leptospirosis however they are still being used in research.

\section{Serology based methods}

Serology based methods for leptospirosis diagnoses are based on the detection of specific antibodies against Leptospira in blood sera. The tests may not work during the initial stage of infection because the antibody production against Leptospira takes a while. Once produced, they may persist in the body for long period of time. Though the initial antibody titer may be low, re-sampling after 3 4 days is recommended for definitive diagnosis. Serological tests for the diagnosis of leptospirosis are both genus and serogroup specific (Levett, 2004) The current serology-based methods emphasize on the detection of IgM and IgC antibodies. IgM antibodies are the first class of antibodies to appear followed by IgG antibodies (Silva et al., 1995). IgM antibody based diagnostic tests for leptospirosis are used to diagnose leptospirosis at an early stage whereas $\operatorname{IgG}$ antibody-based tests are used for later stage leptospirosis diagnosis. This is because of the fact that $\mathrm{IgG}$ antibodies are reported to persist for a longer period of time after infection as compared to $\operatorname{IgM}$ antibodies.

\section{Microscopic agglutination test (MAT)}

Several tests based on antigen-antibody agglutination are being used currently for the diagnosis of leptospirosis. The most common method based on serology used for the diagnosis of leptospirosis is MAT. It is considered to be serogroup/serovar specific when carried out on paired sera. MAT involves the treatment of patient serum sample containing leptospiral antibodies with live antigen. The agglutination between antibody and live antigen is observed under dark field microscope (Mulla et al., 2006). When no free leptospires are observed under the dark field microscope maximum agglutination has occurred. The patient serum samples are continuously diluted till maximum agglutination has occurred and no free leptospires are available. The final serum dilution is the one at which $50 \%$ or more leptospires have undergone agglutination. A number of studies have been carried out which exhibits the variable sensitivity and specificity of MAT in leptospirosis diagnosis. The sensitivity of MAT in diagnosing leptospirosis in the acute phase is considered very less (Limmathurotsakul $\boldsymbol{e t}$ al., 2012)

MAT is considered to be highly sensitive, specific and reliable test for leptospirosis diagnosis. But it requires high expertise to perform and is a cumbersome test for routinely disease diagnosis. Also, for optimal sensitivity a large number of serovar/serogroups residing in a local population has to be included as antigens (Dassanayake et al., 2009). A high degree of crossreactivity between serovars can also produce misleading MAT results. This limits the usefulness of MAT in determining infecting serovar in highly endemic areas. A number of studies have been carried out which revealed the inability of MAT to predict the infecting serovar, given was the antigen pool of that particula region (Subharat, 2010). Another problem with MAT is that it requires working with live antigens which can be bio-hazardous (Ahmed $\boldsymbol{e t}$ al., 2005). The regular sub-culturing is required to keep a check on the authenticity of serovars. The culture maintenance and quality control can be tedious and time consuming.

\section{Enzyme linked immuno sorbent assay (ELISA)}

Enzyme linked immuno sorbent assay is considered to be the easy and simplest method used for leptospirosis diagnosis. It is considered to be more sensitive than most of the serology based tests used for conventional diagnosis of leptospirosis (Wasinki and Pajsek, 2010). ELISA requires minimal training to perform and can give result in a short period of time (usually 2-4 hours). ELISA is based on the detection of antibodies against leptospiral lipoproteins and the outer membrane proteins such as LipL32, LipL21, LipL41, ompL1 and LigB which are highly conserved markers in leptospires. A number of antigen specimen can be used in ELISA such as formalin treated leptospires, sonicated whole cells, polystyrene micro-titer plate coated leptospiral cells, purified and recombinan antigens.

IgM ELISA has been found suitable for the human and animal leptospirosis diagnosis during the acute phase of infection. It is considered to be better than MAT as it can detect IgM antibodies in advance before cut-off MAT titers are reached (Winslow et al., 1997). If antibody titer is low or negative another serum sample should be collected for examining sero-conversion (Vasconcellos $\boldsymbol{e t}$ al., 2010). The other advantage of ELISA over MAT is the use of killed antigen which poses no bio-hazardous threat to laboratory personnel. Due to low specificity of ELISA as compared to MAT for a single sample, convalescent sample testing with MAT is recommended for confirming the results obtained (Cumberland et al., 1999).

\section{Other serological tests}

A number of serological tests have been developed for leptospirosis diagnosis though they are rarely used for routinely diagnosis because of low sensitivity and specificity (Picardeau, 2013). Tests such as hemolysin test (HL), complement fixation (CF) test, indirect haemagglutination assay (IHA), Microcapsule Agglutination test (MCAT), latex agglutination test (LAT), indirect immunofluorescence antibody assay (IFA), lepto dipstick assay, macroscopic slide agglutination test (MSAT), lepto lateral flow lepto dri-dot have been developed (Picardeau, 2014). All these tests are rapid, simple to perform and require no special equipment. A large number of diagnostic kits based on these tests are commercially available in the market.

\section{Molecular methods}

Molecular methods based on DNA-DNA hybridization are considered to be highly specific, sensitive and rapid methods for pathogen detection and disease diagnosis. These methods make use of DNA probe that binds to its complementary counter-part found in clinical samples. PCR has been used in the diagnosis of various infectious diseases caused by bacteria (fastidious organisms). PCR has been used for the detection of leptospires since 1990s. PCR assays based on ompL1, flab, 23S rRNA, LigA, LigB, LipL32 etc. genes have been used extensively for leptospirosis diagnosis. Multiplex PCR has also been used for leptospirosis diagnosis (Kositanont et al., 2007). PCR can detect leptospiral DNA even in culture negative serum samples containing un-cleared non-viable leptospires. Real time PCR or quantitative PCR (qPCR) has been recently used in leptospirosis diagnosis. It has been used for the rapid and sensitive diagnosis of leptospirosis along with quantification of leptospiral DNA (Dezhbord et al., 2014)

Though PCR is considered more sensitive and specific than other tests used for leptospirosis diagnosis it still has got some shortcomings. It uses sophisticated instrumentation and expensive reagents that limits its usefulness for routinely disease diagnosis (Faine et al., 1999). Another limitation of PCR is that it cannot identify the infecting serovar. A newer method known as loop mediated isothermal amplification (LAMP) has been reported to show lesser sensitivity to contaminants present in PCR (Kaneko et al., 2007). Molecular typing using restriction fragment length polymorphism (RFLP), randomly amplified polymorphic DNA (RAPD), fluorescent amplified fragment length polymorphism (FAFLP) and variable number tandem repeat (VNTR) has also been used in the diagnosis of leptospirosis (Gerritsen et al., 1995; Vijayachari et al, 2004; Majed et al., 2005; Slack et al., 2005). However, it is not very specific and reproducible.

\section{TREATMENT}

The treatment of leptospirosis depends on the severity and stage of the infection The patients with symptomatic leptospirosis are advised to keep a check on the progression of the infection and are suggested symptomatic treatment options. The severe form of leptospirosis requires immediate intensive care unit treatmen accompanied by the administration of antibiotics. The various antibiotics recommended for leptospirosis treatment are penicillin, doxycycline, cefotaxime, ceftriaxone and azithromycin (Levett, 2001). In milder cases of leptospirosis infection, oral treatment with tetracycline, doxycycline, ampicillin, or amoxicillin is recommended and penicillin $\mathrm{G}$ and ampicillin are recommended for severe cases. Some cases of leptospirosis require intravenous administration of antibiotics such as penicillin G, erythromycin, amoxicillin and ampicillin. Doxycycline is the best pre-exposure prophylaxis antibiotic but it is not recommended in majority of cases.

\section{CONCLUSION AND FUTURE PROSPECTS}

Leptospirosis is one the important zoonotic infections worldwide. It exhibits diverse clinical manifestations and involves various vital organs of the body. The clinical form of leptospirosis is biphasic in nature involving the initial acute phase and late immune phase characterized by the development of antibodies. The non-availability of efficient diagnostic procedures keeps it underdiagnosed. With the advancement of technology new and efficient methods for leptospirosis diagnosis can help in the management of this disease. Recently, biosensors have gained high importance in disease diagnosis and pathogen detection due to their high sensitivity and specificity. Biosensors for leptospirosis diagnosis will surely help in easy and efficient diagnosis of leptospirosis and thus will play a major role in the management of the disease.

Acknowledgment: The authors are highly thankful to Prof. P.K. Khosla, Shoolini University, Solan (H.P).

Conflict of Interest: There is no conflict of interest among the authors. 


\section{REFERENCES}

ADLER, B., DE LA PENA MOCTEZUMA, A. 2010. Leptospira and leptospirosis. Veterinary Microbiology, 140:287-296. https://doi.org/10.1016/j.vetmic.2009.03.012

AGAMPODI, S.B., MATTHIAS, M.A., MORENO, A.C., VINETZ, J.M. 2012 Utility of quantitative polymerase chain reaction in leptospirosis diagnosis: association of level of leptospiremia and clinical manifestations in Sri Lanka. Clinical Infectious Diseases, 54:1249-1255. https://doi.org/10.1093/cid/cis035 AHMED, I.P. 1987. Serological studies on leptospirosis in Pakistan. Journal of Pakistan Medical Association, 37:233-236. https://doi.org/10.5455/jpma.

AHMED, S.N., SHAH, S., AHMAD, F.M.H. 2005. Laboratory diagnosis of leptospirosis. Journal of Postgraduate Medicine. 51:195-200. https://doi.org/10.5005/jp/books/11617_87

ANDERSON, C.D, FOLLAND, D.S., FOX, M.D., PATTON, C.M., KAUFMANN, A.F. 1978. Leptospirosis: a common-source outbreak due to leptospires of the Grippotyphosa serogroup. American Journal of Epidemiology, 107:538-544. https://doi.org/10.1093/oxfordjournals.aje.a112573

ATZINGEN, M.V., BARBOSA, A.S., BRITO, D.E. 2008. Lsa21, a nove leptospiral protein binding adhesive matrix molecules and present during human infection. BMC Microbiology, 2180:8-70. https://doi.org/10.1186/1471-2180-8 70

BAL, A.E., GRAVEKAMP, C., HARTSKEERL, R.A., MEJA-BREWSTER, J. KORVER, H., TERPSTRA, W.J. 1994. Detection of leptospires in urine by PCR for early diagnosis of leptospirosis. Journal of Clinical Microbiology, 32:1894 1898 .

BARBOSA, A.S., ABREU, P.A., NEVES, F.O. 2006. A newly identified leptospiral adhesion mediates attachment to laminin. Infection and Immunity, 74:6356-6364. https://doi.org/10.1128/iai.00460-06

BARBOSA, A.S., ABREU, P.A., VASCONCELLOS, S.A. 2009. Immune evasion of Leptospira species by acquisition of human complement regulator C4BP. Infection and Immunity, 77:1137-1143. https://doi.org/10.1128/iai.01310 $\underline{08}$

BARCELLOS, C., SABROZA, P.C. 2000. Socio-environmental determinants o the leptospirosis outbreak of 1996 in western Rio de Janeiro: A geographic approach (2000) International Journal of Environmental Health and Research, 10:301-313. https://doi.org/10.1080/0960312002001500

BEUTLER, B. 2004. Inferences, questions and possibilities in Toll-like receptor signaling. Nature, 430(6996): 257-263. https://doi.org/10.1038/nature02761

BHARTI, A.R., NALLY, J.E., RICALDI, J.N., MATTHIAS, M.A., DIAZ, M., LOVETT, M.A., ET AL. 2003. Leptospirosis: a zoonotic disease of global importance. Lancet Infectious Diseases, 3:757-71. https://doi.org/10.1016/s1473 3099(03)00830-2

BHATNAGAR, R.K., SANT, M.V., JHALA, H.L. 1967. Prevalence of leptospirosis in Bombay; studies in man and animals. Indian Journal of Pathology and Bacteriology, 10:324-331.

BOVET, P., YERSIN, C., MERIEN, F., DAVIS, C.E., PEROLAT, P. 1999 Factors associated with clinical leptospirosis: a population-based case-control study in the Seychelles (Indian Ocean) (1999) International Journal of Epidemiology, 28:583-590. https://doi.org/10.1093/ije/28.3.583

BROWN, R.A., BLUMERMAN, S., GAY, C., BOLIN, C., DUBY, R., BALDWIN, C.L. 2003. Comparison of three different leptospiral vaccines for induction of a type 1 immune response to Leptospira borgpetersenii serovar Hardjo. Vaccine, 21:4448-4458. https://doi.org/10.1016/s0264-410x(03)00439-0 BURTH, P., YOUNES-IBRAHIM, M., GONCALEZ, F.H.F.S., COSTA, E.R., FARIA, M.V.C. 1997. Purification and characterization of a $\mathrm{Na}+\mathrm{K}+\mathrm{ATPase}$ inhibitor found in an endotoxin of Leptospira interrogans. Infection and Immunity, 65:1557-1560. https://doi.org/10.1111/j.1749-6632.1997.tb52350.x CACCIAPUOTI, B., NUTI, M., PINTO, A., SABRIE, A.M. 1982. Human leptospirosis in Somalia: a serological survey. Trans Royal Society of Tropical Medicine and Hygiene. 76:178-182. https://doi.org/10.1016/00359203(82)90270-x

CACCIAPUOTI, B., VELLUCCI, A., CICERONI, L. 1987. Prevalence of leptospirosis in man: a pilot survey. European Journal of Epidemiology, 3:137142. https://doi.org/10.1007/bf00239749

CARLES G, MONTOYA E, JOLY F, PENEAU C. 1995. Leptospirosis and pregnancy. Eleven cases in French Guyana, Journal de Gynecologie Obstetrique et Biologie de la Reproduction, 24:418-421.

CHAKURKAR, G., VAIDEESWAR, P., PANDIT, S.P., DIVATE, S.A. 2008 Cardiovascular lesions in leptospirosis: an autopsy study. Journal of Infection, 56:197-203. https://doi.org/10.1016/j.jinf.2007.12.007

CHARON, N.W., GOLDSTEIN, S.F. 2002. Genetics of motility and chemotaxis of a fascinating group of bacteria: The spirochetes. Annual Review Genetics, 36:47-73. https://doi.org/10.1146/annurev.genet.36.041602.134359

CHAURASIA, A. 2016. Leptospirosis- an Indian experience. Air and Water Borne Diseases. 5: e001. https://doi.org/10.4172/2167-7719.s1e001

CHOY, H.A., KELLEY, M.M., CHEN, T.L., MOLLER, A.K., MATSUNAGA J., HAAKE, D.A. 2007 Physiological osmotic induction of Leptospira interrogans adhesion: $\operatorname{Lig} A$ and $\operatorname{Lig} B$ bind extracellular matrix proteins and fibrinogen. Infection and Immunity, 75:2441-2450 https://doi.org/10.1128/iai.01635-06

CICERONI, L., BARTOLONI, A., PINTO, A., GUGLIELMETTI, P. BARAHONA, H.G., ROSELLI, M., ET AL. 1995. Prevalence of leptospiral infections in humans in Cordillera Province, Bolivia. Trans Royal Society of Tropical Medicine and Hygiene, 89:385-386. https://doi.org/10.1016/00359203(95)90019-5

CINCO, M., BAN, M., FURLANI, A., SCARCIA, V. 1980. Cytotoxic activity of supernatant extracts of virulent and saprophytic leptospires. Zentbl Bakteriologie, 248:260-267. https://doi.org/10.1016/s0174-3031(80)80044-8

CORWIN, A., RYAN, A., BLOYS, W., THOMAS, R., DENIEGA, B., WATTS, D. 1990. A waterborne outbreak of leptospirosis among United States military personnel in Okinawa, Japan. International Journal of Epidemiology, 19(3):743 748. https://doi.org/10.1093/ije/19.3.743

CUMBERLAND, P.C., EVERARD, C.O.R., LEVETT, P.N. 1999. Assessmen of the efficacy of the IgM enzyme-linked immunosorbent assay (ELISA) and microscopic agglutination test (MAT) in the diagnosis of acute leptospirosis American Journal of Tropical Medicine and Hygiene, 61:731-734. https://doi.org/10.4269/ajtmh.1999.61.731

DALAL, P.M. 1960. Leptospirosis in Bombay city (report of 5 cases). Indian Journal of Medical Sciences, 14:295-301.

DASSANAYAKE, D.L.B., WIMALARATNA, H., AGAMPODI, S.B. 2009 Evaluation of surveillance case definition in the diagnosis of leptospirosis using matrix agglutination test: a validation study, BMC Infectious Diseases, 9:48 https://doi.org/10.1186/1471-2334-9-48

DEMERS, R.Y., FRANK, R., DEMERS, P., CLAY, M. 1985. Leptospiral exposure in Detroit rodent control workers. American Journal of Public Health, 75:1090-1091. https://doi.org/10.2105/ajph.75.9.1090

DEZHBORD, M., ESMAELIZAD, M., KHAKI, P., FOTOHI, F., ZAREHPARVAR, MOGHADDAM, A. 2014. Molecular identification of the ompL1 gene within Leptospira interrogans standard serovars. Journal of Infection in Developing Countries, 8:688-693. https://doi.org/10.3855/jidc.3174

DORIGATTI, F., BRUNIALTI, M.K., ROMERO, E.C., KALLAS, E.G., SALOMAO, R. 2005. Leptospira interrogans activation of peripheral blood monocyte glycolipoprotein demonstrated in whole blood by the release of IL-6. Brazilian Journal of Medical and Biological Research, 38:909-914 https://doi.org/10.1590/s0100-879x2005000600013

EDWARDS, G.A., DOMM, B.M. 1960. Human Leptospirosis. Medicine (Baltimore), 60; 39:117-156. https://doi.org/10.1097/00005792-196002000 00003

ELLINGHAUSEN, H.C., MCCULLOUGH, W.G. 1965. Nutrition of Leptospira Pomona and growth of 13 other serotypes: fractionation of oleic albumin complex and a medium of bovine albumin and polysorbate 80 . American Journal of Veterinary Research, 26:45-51. https://doi.org/10.1016/b978-0-12-3870506.50012-8

ELLIS, W.A. 2015. Animal leptospirosis. Current Topics in Microbiology and Immunology, 387:99-137. https://doi.org/10.1007/978-3-662-45059-8 6

ELLIS, W.A., MICHNO, S.W. 1976. Bovine leptospirosis: a serological and $\begin{array}{llll}\text { clinical } & \text { study. } & \text { Veterinary } & \text { Records, }\end{array}$ https://doi.org/10.1136/vr.99.20.387

ELLIS, W.A., SONGER, J.G., MONTGOMERY, J., CASSELLS, J.A. 1986 Prevalence of Leptospira interrogans serovar Hardjo in the genital and urinary tracts of non-pregnant cattle. Veterinary Records,118:11-13. https://doi.org/10.1136/vr.118.1.11

EVERARD, C.O.R., FRASER, CHANGPONG, G.M., EVERARD, J.D. 1987. The incidence of severe leptospirosis in Trinidad. Tropical and Geographical Medicine, 39:126-132. https://doi.org/10.1097/00013542-199304000-00007

EVERARD, C.O.R., HAYNES, R.J., EDWARDS, C.N. 1989. Leptospiral infection in school children from Trinidad and Barbados. Epidemiology and Infection, 103:143-156. https://doi.org/10.1017/s0950268800030442

FAINE, S. 1994. Leptospira and leptospirosis. CRC Press Inc., Boca Raton, USA.

FAINE, S. B., ADLER, B., BOLIN, C., PEROLAT, P. 1999. Leptospira and leptospirosis. 2nd ed. Melbourne, Australia: Medicine Sciences.

FAINE, S., STALLMAN, N.D. 1982. Amended descriptions of the genus Leptospira noguchi 1917 and the species interrogans (Stimson 1907) Wenyon 1926 and L. biflexa (Wolbach and Binger 1914) Noguchi 1918. International Journal of Systematic Bacteriology, 32:461-463. https://doi.org/10.1099/00207713-32-4-461

FARR, R.W. 1995. Leptospirosis. Clinical Infectious Diseases, 21:1-6. https://doi.org/10.1093/clinids/21.1.1

FEARNLEY, C., WAKELEY, P.R., GALLEGO-BELTRAN. J., DALLEY, C. WILLIAMSON, S., GAUDIE, C., ET AL. 2008. The development of a real-time PCR to detect pathogenic Leptospira species in kidney tissue. Research in Veterinary Science, 85:8-16. https://doi.org/10.1016/j.rvsc.2007.09.005

GALE, N.B., ALEXANDER, A.D., EVANS, L.B. 1966. An outbreak of leptospirosis among US army troops in the canal zone. American Journal of Tropical Medicine Hygeine, 15:64-70. https://doi.org/10.4269/ajtmh.1966.15.64 
GERRITSEN, M.A., SMITS, M.A., OLYHOEK, T. 1995 Random amplifies polymorphic DNA fingerprinting for rapid identification of leptospires of serogroup Sejroe. Journal of Medical Microbiology, 42:336-339. https://doi.org/10.1099/00222615-42-5-336

GRZESZCZUK, A. 2007. Leptospirosis. In: Cianciara J, Juszczyk J eds Infectious and Parasitic Diseases Lublin, Czelej Sp. z o.o. pp.728-29. https://doi.org/10.1016/b978-1-4160-2406-4.50039-9

GUERREIRO, H., CRODA, J., FLANNERY, B., MAZEL, M., MATSUNAGA, J., GALVAO, M., ET AL. 2001. Leptospiral proteins recognized during the humoral immune response to leptospirosis in humans. Infection and Immunity, 69:4958-4968. https://doi.org/10.1128/iai.69.8.4958-4968.2001

HAAKE, D.A., CHAO, G., ZUERNER, R.L., BARNETT, J.K., BARNETT, D., MAZEL, M., ET AL. 2000. The leptospiral outer membrane protein LipL32 is a lipoprotein expressed during the mammalian infection. Infection and Immunity, 68:2276-85. https://doi.org/10.1128/iai.68.4.2276-2285.2000

HARTSKEEL, R.A. 2002. Report of the leptospirosis outbreak in Indonesia. WHO/FAO/OIE/RIVM leptospirosis Reference Centre, KIT Biomedical Research, Amsterdam. Report submitted to WHO South East Regional Office. HAUK, P., MACEDO, F., ROMERO, E.C., VASCONCELLOS, S.A., DE, MORIAS, Z.M., BARBOSA, A.S., ET AL. 2008. In LipL32, the majo leptospiral lipoprotein, the $\mathrm{C}$ terminus is the primary immunogenic domain and mediates interaction with collagen IV and plasma fibronectin. Infection and Immunity, 76:2642-2650. https://doi.org/10.1128/iai.01639-07

HE, H., WANG, W., WU, Z., LV, Z., LI, J., TAN, L. 2008. Protection of guinea pigs against Leptospira interrogans serovar Lai by LipL21 DNA vaccine. Cellular and Molecular Immunology, 5:385-391. https://doi.org/10.1038/cmi.2008.48

HEUER, C., WILSON, P., BENSCHOP, J. 2008. Leptospirosis- a rising public health hazard? New Zealand Veterinary Association Conference; Wellington. HOVIND-HOUGEN, K. 1976. Determinations by means of electron microscopy of morphological criteria of value for classification of some spirochetes, in particular treponemes. Acta Pathologica, Microbiologica, et immunologica Scandinavia. Sect B Microbiology. 1976; 1-41. https://doi.org/10.1111/j.16990463.1975.tb00076.x

ISOGAI, E., HIROSE, K., KIMURA, K., HAYASHI, S., KUBOTA, T., FUJII, N., ET AL. 1997. Role of platelet-activating-factor (PAF) on cellular responses after stimulation with leptospire lipopolysaccharide. Microbiology and Immunology, 41:271-275. https://doi.org/10.1111/j.1348-0421.1997.tb01200.x IZUREITA, R., GALWANKAR, S., CLEM, A. 2008. Leptospirosis: The "mysterious" mimic. Journal of Emergencies Trauma and Shock, 1:21-33. https://doi.org/10.4103/0974-2700.40573

JOHNSON, R.C., HARRIS, V.G. 1967. Differentiation of pathogenic and saprophytic leptospires: growth at low temperatures. Journal of Bacteriology, 94:27-31. https://doi.org/10.1126/science.157.3788.560

JOSEPH, K.M., KALRA, S.L. 1966. Leptospirosis in India. Indian Journal of Medical Research, 54:611-614.

JOST, B.H., ADLER, B., VIM, T., FAINE, S. 1986. A monoclonal antibody reacting with a determinant on leptospiral lipopolysaccharide protects guinea pig against leptospirosis. Journal of Medical Microbiology, 22:269-275. https://doi.org/10.1099/00222615-22-3-269

KAMATH, S.A., JOSHI, S.R. 2003. Re-emerging of infections in urban India Focus leptospirosis. Journal of Association of Physicians of India, 51:247-48

KANEKO, H., KAWANA, T., FUKUSHIMA, E., SUZUTANI, T. 2007. Tolerance of loop-mediated isothermal amplification to a culture medium and biological substances. Journal of Biochemical and Biophysical Methods, 70:499501. https://doi.org/10.1016/j.jbbm.2006.08.008

KATHRYN， C.M., RATHINAM， R., NAMPERUMALSAMY， P. 1998 Identification of Leptospira species in the pathogenesis of uveitis and determination of clinical ocular characteristics in South India. Journal of Infectious Diseases, 177:1314-1321. https://doi.org/10.1086/515273

KATZ, A.R., ANSDELL, V.E,, EFFLER, P.V., MIDDLETON, C.R., SASAKI, D.M. 2001. Assessment of the clinical presentation and treatment of 353 cases of laboratory-confirmed leptospirosis in Hawaii, 1974-1998. Infectious Disease Clinics of North America, 33:1834-1841. https://doi.org/10.1086/324084

KATZ, R., SASAKI, M., MUMM, H. 1977. Leptospirosis in Oahu: An outbreak among military personnel associated with recreational exposure. Military Medicine, 162:101-104. https://doi.org/10.1093/milmed/162.2.101

KAWAI, T., AKIRA, S. 2007. TLR Signaling. Seminars in Immunology, 19:2432. https://doi.org/10.1016/j.smim.2006.12.004

KELLEY, P.W. 1998. Leptospirosis, 2nd ed., Philadelphia, W. B. Saunders. 1580-87.

KO, A.I., REIS, M.G., DOURADO, C.M.R., JOHNSON, JR, W.D., RILEY, L.W., SALVADOR. 1999 Urban epidemic of severe leptospirosis in Brazil. Leptospirosis Study Group. The Lancet, 354:820-825. https://doi.org/10.1016/s0140-6736(99)80012-9

KOSITANONT, U., RUGSASUK, S., LEELAPORN, A., PHULSUKSOMBATI, D., TANTITANAWAT, S., NAIGOWIT, P. 2007. Detection and differentiation between pathogenic and saprophytic Leptospira spp. by multiplex polymerase chain reaction. Diagnostic Microbiology and Infectious Disease, 57:117-122. https://doi.org/10.1016/j.diagmicrobio.2006.07.014
KRANDE, S., KULKARNI, H., KULKARNI, M., VARAIYA, A. 2002. Leptospirosis in children in Mumbai slums. Indian Journal of Pediatrics, 69:855888. https://doi.org/10.1007/bf02723705

KSHIRSAGAR, N.A., SHINDE, R.R., MEHTA, S. 2006. Floods in Mumbai impact of public health service by hospital staff and medical students. Journal of Postgraduate Medicine, 52:312-314.

LANGSTON, C.E., HEUTER, K.J. 2003. Leptospirosis: A re-emerging zoonotic disease. Veterinary Clinics of North America: Small Animal Practice, 33:791807. https://doi.org/10.1016/s0195-5616(03)00026-3

LAROCQUE, R.C., BREIMAN, R.F., ARI, M.D., MOREY, R.E., JANAN, F.A. HAYES, J.M., ET AL. 2005. Leptospirosis during dengue outbreak, Bangladesh. Emerging Infectious Diseases, 11:766-769. https://doi.org/10.3201/eid1105.041212

LEBLEBICIOGLU, H, IRFAN, M. 1996. Weils disease, Report of 12 cases. Scandinavian Journal of Infectious Diseases, 28:637 639. https://doi.org/10.3109/00365549609037976

LEE, S.H., KIM, S., PARK, S.C., KIM, M.J. 2002. Cytotoxic activities of Leptospira interrogans hemolysin $\operatorname{SphH}$ as a pore-forming protein on mammalian cells. Infection and Immunity, 70:315-322. https://doi.org/10.1128/iai.70.1.315-322.2002

LEVETT, P.N. 2001. Leptospirosis. Clinical Microbiology Reviews, 14: 296-326. https://doi.org/10.1128/cmr.14.2.296-326.2001

LEVETT, P.N. 2004. Leptospirosis: A forgotten zoonosis? Clinical and Applied Immunology Reviews, 4:435-48. https://doi.org/10.1016/j.cair.2004.08.001

LEVETT, P.N., MOREY, R.E., GALLOWAY, R.L., STEIGERWALT, A.G. 2006. Leptospira broomii sp. nov., isolated from humans with leptospirosis International Journal of Systematic and Evolutionary Microbiology, 56:671-673. https://doi.org/10.1099/ijs.0.63783-0

LEVETT, P.N., MOREY, R.E., GALLOWAY, R.L., STEIGERWALT, A.G. 2006. Leptospira broomii sp. nov., isolated from humans with leptospirosis. International Journal of Systematic and Evolutionary Microbiology, 56:671-673. https://doi.org/10.1099/ijs.0.63783-0

LIMMATHUROTSAKUL, D., TURNER, E.L., WUTHIEKANUN, V., THAIPADUNGPANIT, J., SUPUTTAMONGKOL, Y., CHIERAKUL, W., ET AL. 2012. Fool's gold: why imperfect reference tests are undermining the evaluation of novel diagnostics: A re-evaluation of 5 diagnostic tests for leptospirosis. Clinical Infectious Diseases, 55:322-331. https://doi.org/10.1093/cid/cis403

LIU, Y., ZHENG, W., LI, L., MAO, Y., YAN, J. 2007. Pathogenesis of leptospirosis: interaction of Leptospira interrogans with in vitro cultured mammalian cells. Medical Microbiology and Immunology, 196:233-239. https://doi.org/10.1007/s00430-007-0047-0

MAJED, Z., BLLENGER, E., POSTIC, D., POURCEL, C., BARANTON, G., PICARDEAU, M. 2005. Identification of variable number tandem repeat loci in Leptospira interrogans sensu stricto. Journal of Clinical Microbiology, 43:539545. https://doi.org/10.1128/jcm.43.2.539-545.2005

MASALI, K.A., PULARE, M.W., KACHARE, V.K., PATIL, M.B., REDDI, S. 2007. Control and prevention of rat fever (leptospirosis) outbreak in six villages of Raichur district, Karnataka. Journal of Indian Medical Association, 105:632636.

MATTHIAS, M.A., LEVETT, P.N. 2002. Leptospiral carriage by mice and mongooses on the island of Barbados. West Indian Medical Journal, 51:10-13.

MOGENSEN, T.H. 2009. Pathogen recognition and inflammatory signaling in innate immune defenses. Clinical Microbiology Reviews, 22:240-273. https://doi.org/10.1128/cmr.00046-08

MULLA, S., CHAKRABORTY, T., PATEL, M., PANDYA, H.P. DADHANIYA, V., VAGHELA, G. 2006. Diagnosis of leptospirosis and comparison of ELISA and MAT techniques. Indian Journal of Pathology and Microbiology, 49:468-470

MUSO, D., LA SCOLA, B. 2013. Laboratory diagnosis of leptospirosis: a challenge. Journal of Microbiology Immunology and Infection, 46:245-252. https://doi.org/10.1016/j.jmii.2013.03.001

MUTHUSETHUPATHI, M.A., SHIVAKUMAR, S. 1987. Acute renal failure due to leptospirosis. Journal of Association of Physicians in India, 35:631-633. MUTHUSETHUPATHI, M.A., SHIVKUMAR, S., SUGUNA, R. JAYAKUMAR, M., VIJAYAKUMAR, R., EVERARD, C.O., ET AL. 1995. Leptospirosis in Madras-a clinical and serological study. Journal of Association of Physicians in India, 43:456-458

MWACHUI, M.A/, CRUMP, L/, HARTSKEERL, R., ZINSSTAG, J., HATTENDORF, J. 2015. Environmental and behavioural determinants of leptospirosis transmission: a systematic review. PLOS Neglected Tropical Diseases, 9: e0003843. https://doi.org/10.1371/journal.pntd.0003843

NUTI, M., AMADDEO, D., CROVATTO, M. 1993. Infections in an alpine environment: antibodies to hantavirus, Leptospira, rickettsiae and Borrelia burgdorferi in defined Italian populations. The American Journal of Tropical Medicine and Hygiene, 48:20-25. https://doi.org/10.4269/ajtmh.1993.48.20

O'KEEFE, J.S. 2002. A brief review on the laboratory diagnosis of leptospirosis. New Zealand Veterinary Journal, 50:9-13. https://doi.org/10.1080/00480169.2002.36242 
PAPPAS, G., PAPADIMITRIOU, P., SIOZOPOULOU, V., CHRISTOU, L. AKRITIDIS, N. 2002. The globalization of leptospirosis: worldwide incidence trends. International Journal of Infectious Diseases, 12:351-357. https://doi.org/10.1016/j.ijid.2007.09.011

PARK, S.K., LEE, S.H., RHEE, Y.K., CHANG, W.H. 1989. Leptospirosis in Chonbuk province of Korea in 1987: a study of 93 patients. The American Journal of Tropical Medicine and Hygiene 41:345-351. https://doi.org/10.4269/ajtmh.1989.41.345

PICARDEAU, M. 2017. Virulence of the zoonotic agent of leptospirosis: still terra incognita? Nature Reviews Microbiology, 15:297-307. https://doi.org/10.1038/nrmicro.2017.5

PICARDEAU, M., BERTHERAT, E., JANCLOES, M., SKOULOUDIS, A.N., DURSI, K., HARTSKEERL, R.A. 2014. Rapid tests for diagnosis of leptospirosis: current tools and emerging technologies. Diagnostic Microbiology and Infectious Disease, 78:1-8. https://doi.org/10.1016/j.diagmicrobio.2013.09.012

PICARDEAU, M., BULACH, D.M., BOUCHIER, C., ZUERNER, R.L., ZIDANE, N., WILSON, P.J., ET AL. 2008. Genome sequence of the saprophyte Leptospira biflexa provides insights into the evolution of Leptospira and the pathogenesis of leptospirosis. PloS One, 3: e1607. https://doi.org/10.1371/journal.pone.0001607

PRABHAKAR, P.K., HARISH, B.N., RAO, R.S. 1995. Seroprevalence of Leptospirosis among febrile and jaundice patients. Indian Journal of Medical Microbiology, 13:189-191

QUE-GEWIRTH, N.S., RIBERIO, A., KALB, S.R., COTTER, R.J., BULACH, D.M., ADLER, B., ET AL. 2004. A methylated phosphate group and four amidelinked acyl chains in Leptospira interrogans Lipid A. Journal of Biological Chemistry, 279:25420-25429. https://doi.org/10.1074/jbc.m400598200

RATNAM, S. 1994. Leptospirosis: An Indian perspective. Indian Journal of Medical Microbiology, 12:228-239.

RATNAM, S., EVERARD, C.O., ALEX, J.C., SURESH, B., THANGARAJU, P 1993. Prevalence of leptospiral agglutinins among conservancy workers in Madras City. The Journal of Tropical Medicine and Hygiene, 96:41-45. https://doi.org/10.1093/ww/9780199540884.013.u241179

RATNAM, S., SUNDARARAJ, T., THYAGARAJAN, S.P. 1983. Serological evidence of leptospirosis in jaundice and pyrexia of unknown origin. Indian Journal of Medical Research, 77:430. https://doi.org/10.1016/00359203(83)90027-5

RISTOW P, BOURHY P CRUZ, MCBRIDE FW (2007) The OmpA-like protein Loa22 is essential for leptospiral virulence. PLoS Pathogen 3: e97. https://doi.org/10.1371/journal.ppat.0030097

ROTH, E.E., LINDER, D., ADAMS, W.V. 1961. The use of agar plates as an aid for the isolation of leptospires. American J Vet Res 22:308-312. https://doi.org/10.2307/4591135

SARAVANAN, R. 1998. First report of human leptospirosis due Leptospira interrogans serovar Javanica in Indian. . Trans Royal Society of Tropical Medicine and Hygiene, 92:186. https://doi.org/10.1016/s0035-9203(98)90743-x SCHREIER, S., DOUNGCHAWEE, G., CHADSUTHI, S., TRIAMO, D., TRIAMO, W. 2013. Leptospirosis: current situation and trends of specific laboratory tests. Expert Review in Clinical Immunology, 9:263-280. https://doi.org/10.1586/eci.12.110

SEHGAL, S.C. 1998. Emergence of leptospirosis as a public health problem. In the proceedings of the third round table conference, series-leptospirosis. Ranbaxy Science Foundation. pp. 7-12.

SEHGAL, S.C. 2000. Leptospirosis in the horizon. Nat Med J Ind 13:228-230. SEHGAL, S.C., MURHEKAR, M.V., SUGUNAN, A.P. 1995. Outbreak of leptospirosis with pulmonary involvement in North Andaman. Indian Journal of Medical Research, 102:9-12.

SEHGAL, S.C., SUGUNAN, A.P., VIJAYACHARI. 2001. Outbreak o leptospirosis after cyclone in Orissa. The National Medical Journal of India, 15:22-23.

SEJVAR, J., BANCROFT, E., WINTHROP, K., BETTINGER, J., BAJANI, M., BRAGG, S., ET AL. 2000. Eco-challenge investigation team 2003 leptospirosis in "Eco-Challenge" athletes, Malaysian Borneo. Emerging Infectious Diseases 9:702-07. https://doi.org/10.3201/eid0906.020751

SHARMA, S.P., VIJAYACHARI, A.P., SUGNAN, K., NATARAJA, S. SEHGAL, A.C. 2006. Seroprevalence of leptospirosis among high-risk population of Andaman Island, India. American Journal of Tropical Medicine and Hygiene, 74:278-283. https://doi.org/10.4269/ajtmh.2006.74.278

SHERE, T.A., UJIIE, M., SUZUKI, M., SALVA, E., BELO, M.C., KOIZUMI, N., ET AL. 2012. Outbreak of leptospirosis after flood, the Philippines, 2009. Emerging Infectious Disease, 18:91-94. https://doi.org/10.3201/eid1801.101892 SHIMIZU, T., MATSUSAKA, E., TAKAYANAGI, T., MASUZAWA, T. IWAMOTO, Y., MORITA, T., ET AL. 1987. Biological activities of lipopolysaccharide-like substance (LLS) extracted from Leptospira interrogan serovar Canicola strain Moulton. Microbiology and Immunology, 31:727-735. https://doi.org/10.1111/j.1348-0421.1987.tb03134.x

SILVA, M.V., CAMARGO, E.D., BATISTA, L., VAZ, A.J., BRANDÃO, A.P., NAKAMURA, P.M., ET AL. 1995. Behaviour of specific $\operatorname{IgM}, \operatorname{IgG}$ and $\operatorname{IgA}$ class antibodies in human leptospirosis during the acute phase of the disease and during convalescence. Journal of Tropical Medicine and Hygiene, 98:268-272. https://doi.org/10.4269/ajtmh.1997.56.650

SLACK, A.T., DOHNT, M.F., SYMONDS, M.L., SMYTHE, L.D. 2005. Development of a multiple-locus variable number of tandem repeat analysis (MLVA) for Leptospira interrogans and its application to Leptospira interrogans serovar Australis isolates from Far North Queensland, Australia. Annals of Clinical Microbiology and Antimicrobials, 4:10. https://doi.org/10.1099/jmm.0.46779-0

SUBHARAT, S., WILSON, P.R., HEUER, C., COLLINS-EMERSON, J.M. 2010. Investigation of localisation of Leptospira spp. in uterine and fetal tissues of non-pregnant and pregnant farmed deer. New Zealand Medical Journal, 58:281-285. https://doi.org/10.1080/00480169.2010.69755

TANGKANAKUL, W., KINGNATE, D. 1998. Leptospirosis epidemic in northeastern provinces of Thailand, 1997. Health Science, 7:386-95 https://doi.org/10.4269/ajtmh.2000.63.204

TAYLOR, J., GOYLE, AN. 1931. Leptospirosis in Andamans. Indian medical research memoirs no. 20. Indian Journal of Medical Research, 20:55-56. https://doi.org/10.2307/3271745

TERRY, J., TRENT, M., BARTLETT, M. 2000. A cluster of leptospirosis among abattoir workers. Communicable Disease Intelligence, 24:158-160. https://doi.org/10.1515/labm.2000.24.3.158

THOMAS, M.C., CHERESHSKY, M., MANNING, K. 1994. An outbreak of leptospirosis on a single farm in East Otago. New Zealand Medical Journal, 107:290-291. https://doi.org/10.1093/ww/9780199540884.013.u225328

THORNLEY, C.N., BAKER, M.G., WEINSTEIN, P., MAAS, E.W. 2002. Changing epidemiology of human leptospirosis in New Zealand. Epidemiology Infections, 128:29-36. https://doi.org/10.1017/s0950268801006392

VARNI, V., KOVAL, A., NAGEL, A., RUYBAL, P., CAIMI, K., AMADIO, A.F. 2016. First genome sequence of Leptospira interrogans serovar Pomona isolated from a bovine abortion. Genome Announcements, 4: e00345-16. https://doi.org/10.1128/genomea.00345-16

VASCONCELLOS, F.A., COUTINHO, M.L., DA, SILVA, E.F., FERNANDES, C.P., MONTE, L.G., SEYFFERT, N. 2010. Testing different antigen capture ELISA formats for detection of Leptospira spp. in human blood serum. Trans Royal Society of Tropical Medicine and Hygiene, 104:259-264. https://doi.org/10.1016/j.trstmh.2009.10.005

VELINENI, S., ASUTHKAR, S., UMABALA, P., LAKSHMI, V. SRITHARAN, M. 2007. Serological evaluation of leptospirosis in Hyderabad, Andhra Pradesh: A retrospective hospital-based study. Indian Journal of Medical Microbiology, 25:24-27. https://doi.org/10.4103/0255-0857.31057

VENKATARAMAN, K.S., RAMAKRISHNA, J., RAGHAVAN, N. 1991 Human leptospirosis: a recent study in Madras, India. Trans Royal Society of Tropical Medicine and Hygiene, 85:304. https://doi.org/10.1016/0035 9203(91)90068-a

VIJAYACHARI, P., AHMED, NIYAZ., SUGUNAN, A.P., GHOUSUNNISSA, SHEIKH., RAJENDER, K., HASNAIN, SE., ET AL. 2004. Use of fluorescen amplified fragment length polymorphism for molecular epidemiology of leptospirosis in India. Journal of Clinical Microbiology, 42:3574-3580. https://doi.org/10.1128/jcm.42.8.3575-3580.2004

VIJAYACHARI, P., SEHGAL, S.C., MARGA, G.A., GORIS, W., TERPSTRA, J., HARTSKEERL, RA (2003) Leptospira interrogans serovar Valbuzzi: a cause of severe pulmonary haemorrhages in the Andaman Islands. Medical Microbiology, 52:913-918. https://doi.org/10.1099/jmm.0.05094-0

VIJAYACHARI, P., SUGUNAN, A.P., SHRIRAM, A.N. 2008. Leptospirosis an emerging global public health problem. Journal of Bioscience, 2008; 33:557569. https://doi.org/10.1007/s12038-008-0074-Z

VINETZ, J.M. 2001. Leptospirosis. Current Opinion in Infectious Diseases, 14:527-538. https://doi.org/10.1097/00001432-200110000-00005

VINH, T., ADLER, B., FAINE, S. 1986. Ultrastructure and chemica composition of lipopolysaccharide extracted from Leptospira interrogans serovar Copenhageni. Journal of General Microbiology, 132:103-109. https://doi.org/10.1099/00221287-132-1-103

WAITKINS, S.A. 1987. Leptospirosis. In: Manson's Tropical Diseases, 19th edn. Manson-Bhor PEC, Bell DR. London, Bailliére Tindall. 1987; pp. 657-65. https://doi.org/10.1016/b978-0-7236-0739-7.50012-3

WANG, C., JOHN, L., CHANG, T., CHENG, W., LUO, M., HUNG, A. 1965. Studies on anicteric leptospirosis. I. Clinical manifestations and antibiotic therapy. Chinese Medical Journal, 84:283-291.

WASINSKI, B., PEJSAK, Z. 2010. Occurrence of leptospiral infections in swine population in Poland evaluated by ELISA and microscopic agglutination test. Polish Journal of Veterinary Sciences, 3:695-699. https://doi.org/10.2478/v10181-010-0006-3

WERTS, C., TAPPING, RI., MATHISON, J.C., CHUANG, T.H. KRAVCHENKO, V., SAINT GIRONS, I., ET AL. 2001. Leptospiral lipopolysaccharide activates cells through a TLR2-dependent mechanism. Nature Immunology, 2:346-352. https://doi.org/10.1038/86354

WINSLOW, W.F., MERRY, D.J., PIRE, M.I., DEVINE, P.I. 1997. Evaluation of commercial enzyme linked immunosorbent assay for the detection of immunoglobulin M antibodies in the diagnosis of human leptospirosis. Journal of Clinical Microbiology, 35:1938-1942. 
YENER, Z., KELES, H. 2001. Immunoperoxidase and histopathological examinations of leptospiral nephritis in cattle. Journal of Veterinary Medical Association, 48:441-447. https://doi.org/10.1046/j.1439-0442.2001.00355.X

YERSIN, C., BOVET, P., MERIEN, F., WONG, T., PANOWSKY, J., PEROLAT, P. 1998. Human leptospirosis in the Seychelles (Indian Ocean): a population-based study. American Journal of Tropical Medicine and Hygiene, 59:933-940. https://doi.org/10.4269/ajtmh.1998.59.933

ZAKI, S.R., SHEIH, W.J. 1996. Leptospirosis associated with outbreak of acute febrile illness with pulmonary hemorrhage, Nicaragua, 1995. The epidemic working group at Ministry of Health in Nicaragua. Lancet, 347:535-536. https://doi.org/10.1016/s0140-6736(96)91167-8

ZHANG, Y.X., GENG, Y., BI, B., HE, J.Y., WU, C.F., GUO, X.K., ET AL 2005. Identification and classification of all potential hemolysin encoding genes and their products from Leptospira interrogans serogroup Icterohaemorrhagiae serovar Lai. Acta Pharmacologica Sinica, 26:453-461. https://doi.org/10.1111/j.1745-7254.2005.00075.x 